\title{
DE DE GRUYTER \\ OPEN \\ Customer trust as mediator in the creation of customer relationship intention
}

\author{
Mohamad DIMYATI \\ The Faculty of Economics and Business University of Jember, Indonesia \\ dimyati.feb@unej.ac.id \\ N. Ari SUBAGIO \\ The Faculty of Economics and Business University of Jember, Indonesia
}

\begin{abstract}
As in all service industries, banks need to be able to provide their customers with personalized services in order to ensure that they build and maintain long-term relationships which are mutually beneficial. As such, banks must adopt a relational marketing approach based on effective communication and the building of trust with the current customers instead of focusing on acquiring new customers. The current research provides insights into how banks can build trust and maintain their relations with existing customers by testing several predictors of customer trust and customer relationship intention. Thus, the purpose of this study is to examine economic content, resource content and social content as the predictors of trust and relationship intention, and trust as a predictor of relationship intention. In addition, this study also analyzes the role of trust in mediating among economic content, resource content, and social content as a predictor of relationship intention of state owned bank customers in East Java. The sample of the study is formed of 120 customers of three stateowned banks from East Java. The research variables consist of three exogenous variables: economic content, resource content, and social content. The endogenous variables are trust and relationship intention. The data was collected using a questionnaire with multiple items measured using Likert scales. The model was analyzed using SEM with AMOS version 18.0. The result shows that economic content, resource content and social content are positive and significant predictors of trust and relationship intention. The role of economic content, resource content, social content as direct predictors is higher than the mediating role of trust of state owned bank customers.
\end{abstract}

Keywords: economic content, resource content, social content, trust, relationship intention.

Please cite the article as follows: Dimyati, M. and Subagio, N.A. (2018), "Customer trust as mediator in the creation of customer relationship intention", Management \& Marketing. Challenges for the Knowledge Society, Vol. 13, No. 1, pp. 710-729, DOI: 10.2478/mmcks-2018-0001.

\section{Introduction}

Globalization has led to a dramatic increase in the level of competitiveness in all business sectors around the world, including the banking and financial services sectors in Indonesia which are facing increasingly stricter competition from the foreign banks which have entered the Indonesian market. Moreover, the emergence of non-banking financial institutions which provide specialized services has also contributed to the increase in the level of competition. In general, the conditions of competition in Indonesian banking and financial services sector have become quite complex and the general environment has changed very fast in the last couple of years, which has meant an opportunity for customers to change their purchase behavior in order to search for better financial services.

Everywhere around the world, customers leave those banks which do not give them the required attention and switch to another bank (Beckett et al., 2000). This is happening 
because the rapid changes in technological industry have directly raised the competitive environment within the service industry (Lavelock, 2004). Therefore, banks should be able to create a good service that is able to touch customers personally. The customer's personal touch in banking service can be created by building and managing long-term relationships with customers through mutual communication. This kind of activity is known as relationship marketing and a business philosophy that focuses an organization's strategy on maintaining and improving relations with existing customers rather than acquiring new customers (Zeithaml and Bitner, 2003). Customers who continue to do business with the company in the long run are more beneficial for the business because: a) this reduces the costs necessary to attract and serve customers for the first time; b) when the customer feel the comfort of their spending they will probably spend more on the same services or buy more services; and c) long-term customers are also more likely to encourage others to do business with the firm than one-time or short term customers (Barney, 2001).

Relationship intention refers to a strong desire of the customer to develop a longterm relationship with the company and this is the actual behavior of customers (Kumar et al., 2003). Relationship intention is formed through customer ratings of the activities of the company and it is influenced by the customer's trust, which is an important factor for the development and existence of successful relation (Dwyer et al., 1987). Trust is a key element of successful long-term relationships because customers' trust affects the intention of their future behavior. This is supported by the results of research from Venetis and Ghauri (2004) and Dimyati (2010) who found that trust positively and significantly affects relationship intention. Furthermore, Dimyati (2010) found that trust acts as an intermediate variable which plays an important role in forming long-term relationships.

There are three important factors that develop trust and effective cooperation in relational marketing, namely economic content, resource content, and social content. Economic content is represented by the economic benefits received by participants involved in the relationship. Resource content is a corporate resource that can be used to build a relationship with a partner, while social content is the social interaction that occurs between buyers and sellers (Morgan, 2000). These interactions can strengthen the relationships between customers and companies (Bendapuli and Leone, 2002).

Economic content can affect customer trust. Customers are encouraged to believe in the service provider which offers economic content as the party that can be trusted. The truthfulness of these offers is defined as the capability of the service provider. This capability can lead to customer trust, which means a positive assessment of the bank's ability to meet its obligations (Lin et al., 2003; Donney and Cannon, 1997). Resource content significantly affects customer's trust. Customers have a high level of trust in a company that has resources that are reliable and will not cause problems for them. Resource content is perceived as part of the services performance which is able to meet customer desires and expectations thus affect customer trust. Banks that have high skill resources to serve the customer need will lead to customer trust, because the resource content is considered valuable and important to the customer. Thus, resource content is a corporate resource that can be used to build relationships with customers, and has a strategic role in developing long-term relationships with customers (Morgan and Hunt, 1994). 
Finally, the company's ability to build and maintain a relationship is based on the ownership of a unique valuable resource, rare, and difficult to replicate. Unique resources are often intangible because this makes it difficult for competitors to imitate. One example of such a unique resource is represented by social content which refers to the interaction between providers and customers (Morgan, 2000). Social interactions that occur between the customer and the employees will lead to an understanding of each party so as to make both sides understand each other therefore help them to avoid misunderstandings. Social interactions help employees have a good understanding of customers' needs so that they can meet those needs and the constant interaction between the bank's employees and customers builds customer trust.

The value of a relationship is associated with the belief that relational trust only exists when the relationship is considered important. In addition, the company will continue to maintain a relationship only when their partner commits the relation as well. Trust is a very important component of a long-term relationship between the company and their partner. Trust in relationship is the key to successful relationship marketing (Morgan and Hunt, 1994). Trust has a direct impact on the cooperative behavior of the partners which in turn leads to the success of relationship marketing.

This study aims to examine economic content, resources content, and social content as predictors of customers' trust and relationship intention, and then trust as a predictor of the intention of the customer for a relationship with the company. In addition, this study will also analyze the role of trust in mediating economic content, resources content, social content as predictors of customers of the BNI, BRI, Bank Mandiri in East Java to maintain their relationship with those banks. This study will test seven hypotheses: (1) economic content as a predictor of trust, (2) resource content as a predictor of trust, (3) social content as a predictor of trust, (4) economic content as a predictor of relationship intention, (5) resource content as a predictor of relationship intention, (6) social content as a predictor of relationship intention, and (7) the trust relationship as a predictor of the intention of BNI, BRI and Bank Mandiri customer in East Java to maintain their relationships with the respective banks.

\section{Literature review}

The most common definition of economic content, which is what partners in market-based transactions usually focus on, was provided by Morgan (2000): economic content is represented the economic benefits which result for all participants in a certain relationship. As Zeithaml and Bitnet (2003, p. 175) argue, customers engage in relationship with businesses because of the financial incentives that result from that bond. Thus, customers are mainly motivated to pursue those relationship which bring them the highest economic content (Peterson, 1995). This economic content is reflected in the economic value perceived by the customer and the costs of switching to another provider for similar services or products (Lacey, 2003). Economic value results from the cost-benefit analysis performed by all parties involved in the relationship. Success in delivering economic value to customers can improve quality and minimize customer costs. As a result, Parvatyar and Sheth (2000) recommend companies seeking to enlarge their relationships with their customers to charge lower costs for their services and products. Switching costs are defined as consumers' perception of the time, money and effort required to replace the brand or 
company. Switching costs may include the search cost, learning cost, relationship-specific investments, and so on. Switching cost is defined as the costs associated with the process of switching from one supplier to another supplier (Burnham et al., 2003).

Companies looking to built stronger relationships with others have to rely on resources content which is unique, valuable and difficult to replicate (Morgan and Hunt, 1994). For example, resource content can be represented by the company's reputation and confidence benefit, two intangible resources which competitors find it hard to imitate (Lacey, 2003; Boonajsevee, 2005; Morgan, 2000). The company's reputation is reflected by the customer's perception of the quality associated with the name of the company (Lacey, 2003). This means that the name of the company has a positive effect on the customer's response to the product or service. The company's reputation for quality is not limited to the products or services produced as is often associated with the company's reputation as a whole. The company's quality reputation is the reflection of the perception of customers of past actions and future prospects regarding the products and services of the company. Confidence benefit is associated with the company's ability to reduce customers' anxiety and provide comfort by letting the customers know what to expect from the company (Gwinner et al., 1998). According to Sheth and Parvatiyar (2000), the consumer is willing to engage in long-term relationships with businesses because they want to reduce risk, and enjoy the convenience. Thus, consumers can establish relationships with particular brands or companies to reduce doubts about the products or services they acquire.

Social content refers to the social bond that is formed from the interaction between the business and its customers (Morgan, 2000). The interaction between business and their customers always produces social content and when this is based on feelings of love and friendship and social interactivity, this makes customers willing to improve the relationships by participating more fully in the communication and information exchange (Lacey, 2003; Morgan, 2000). Thus, communication between businesses and customers, the fundamental building block of relationships, represents one of the main functions of interactive marketing (Gronroos, 1996). Communication can be broadly defined as sharing meaningful and timely information between the company and its customers, both formally and informally. Timely communication can speed up the trust by helping to resolve miscommunications that negatively affect customers' perceptions and expectations. Some relational marketing experts agree that communication is a fundamental aspect in developing a relationship with customers.

Trust is represented by the belief of the customer that he or she will find what they want from their exchange partners. Trust involves the willingness to behave in particular way because the parties expect the exchange to deliver what is promised (Barnes, 2003). There are three components of trust are: credibility, reliability, and intimacy. Credibility implies that employees are honest and trustworthy. Reliability means providing the service or products in the promised format and in the promised time frame. Intimacy is associated with the premises of employee integrity which is reflected in the degree to which employees have strong moral values (Green in Peppers, 2004). Walter et al. (2000) that beliefs in relationships have three main parts: a) that the partners will act in the interest of maintaining the relationship; b) that the partners will be honest with each other; and c) that the parties will be able to act in the benefit of the relationship. Thus, trust 
is a very important component in the long-term relationship between companies and their exchange partners. Companies decide to maintain relationships when they think that their partner is also committed to the relationship and this can result in long term relationships (Morgan and Hunt, 1994).

Relationship intention is the intention of the customer to build a relationship with a business while buying a product or service attributed to a business, a brand, and a channel. The relationship intention can be measured by looking at forgivingness, feedback, and the fear of relationship loss (Kumar et al., 2003). Forgivingness happens when a customer who wants to build a relationship with the company in general is willing to forgive the company even if the expectations are not met. It means, although sometimes customer expectations are not met, the customer still provides another opportunity for the company because the relationship is more important to the customer. Feedback happens when customers with high intention relationship tend to communicate their expectations to the company in the form of feedback, whether positive or negative without expecting anything in return. On the other hand, customers who do not have intention relationship can also send a negative feedback to the company. This kind of customers expects reward or payback. Thus, customers who are willing to provide feedback without expecting anything in return have a high relationship intention. Fear of relationship loss happens when customers pay attention to the consequences of a lost relationship with their partner while doing a transaction, and in this case customers are showing a high desire to build a relationship. Figure 1 presents the conceptual research framework.

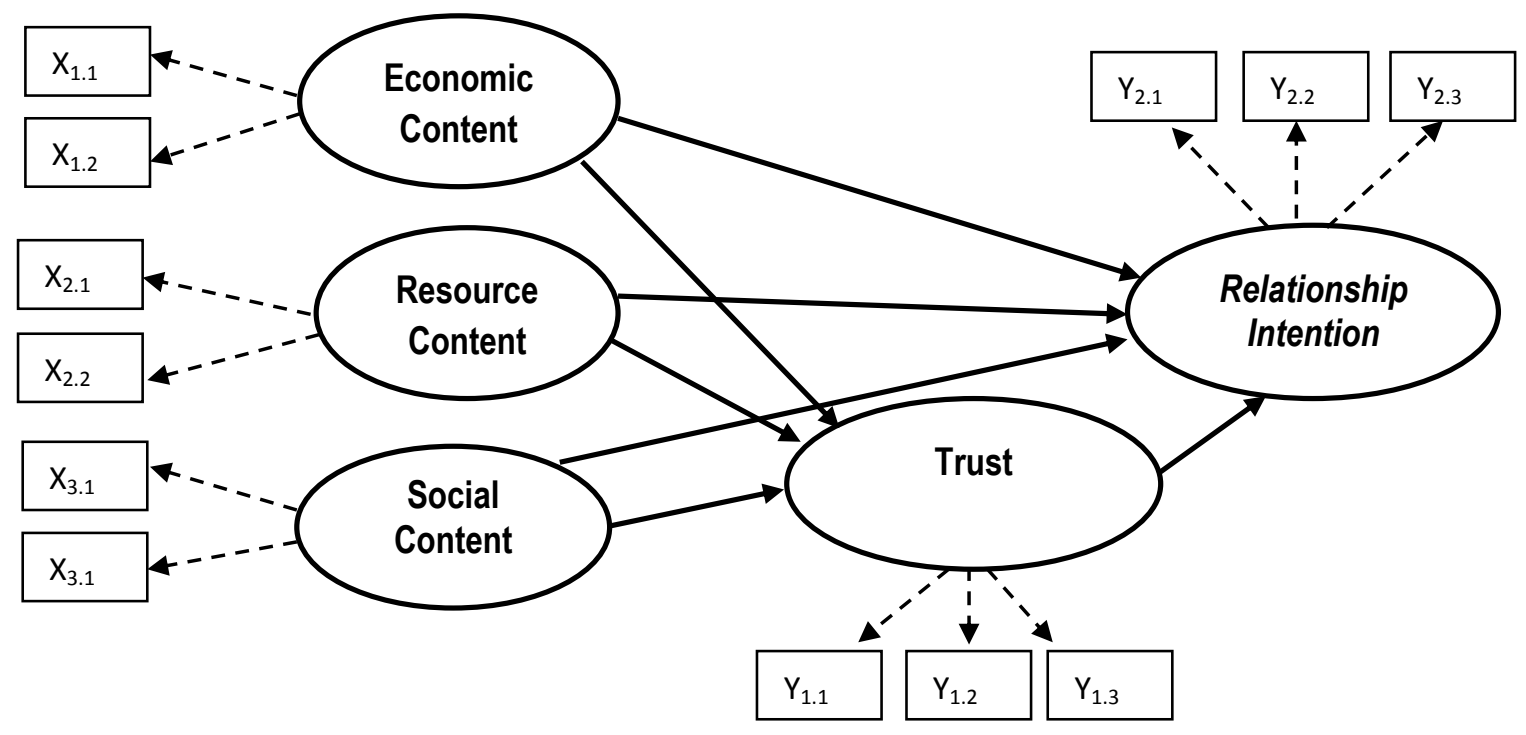

Figure 1. Conceptual framework

Source: Authors' own research contribution.

\section{Research methods}

The population of this study is formed of the customers of BNI, BRI and Bank Mandiri in East Java. The sampling method is purposive sampling, and samples were taken in three cities in East Java province. Surabaya is a large city, Malang is a medium city and Jember is a small city. The respondents were chosen from customers who came to the bank. The 
researchers choose this approach because of lack of access to a complete database with the customers' residence addresses. The banks could not provide customers' addresses due to bank secrecy regulations. The data was collected with using a questionnaire. The number of respondents was set to 120 , this representing the number of indicators across the latent variables multiplied by 10 . The number of respondents was also based on the analysis model Structural Equation Modeling (SEM) (Ferdinand, 2006). The number of respondents that fit within the model SEM is between 100-200 respondents (Ghozali, 2004).

The research variables were classified into exogenous and endogenous variables. Exogenous variables consist of: Economic content $\left(\mathrm{X}_{1}\right)$ with indicators of economic value $\left(\mathrm{X}_{1.1}\right)$ and switching cost $\left(\mathrm{X}_{1.2}\right)$; Resource content $\left(\mathrm{X}_{2}\right)$ with indicators of the bank's reputation $\left(\mathrm{X}_{2.1}\right)$ and confidence benefit $\left(\mathrm{X}_{2.2}\right)$; Social content $\left(\mathrm{X}_{3}\right)$ with communication indicator $\left(\mathrm{X}_{3.1}\right)$ and familial indicator $\left(\mathrm{X}_{3.2}\right)$. The endogenous variables consist of: Customer trust $\left(\mathrm{Y}_{1}\right)$ with indicators: employee trustworthiness ( $\left.\mathrm{Y}_{1.1}\right)$, bank reliability $\left(\mathrm{Y}_{1.2}\right)$, and employee integrity ( $\left.\mathrm{Y}_{1.3}\right)$; Relationship intention $\left(\mathrm{Y}_{2}\right)$ with indicators for forgiveness $\left(\mathrm{Y}_{2.1}\right)$ and willingness to give a feedback $\left(\mathrm{Y}_{2.2}\right)$, and the fear of losing the relationship $\left(\mathrm{Y}_{2.3}\right)$. Data measurement was done using a Likert scale with five alternative answers, strongly agree (5), agreed (4), neutral (3), disagree (2) and strongly disagree (1). Likert scale is an interval scale (Indriantoro and Supomo, 2002; Sekaran 2003). Hypothesis testing was performed using structural equation modeling in AMOS version 18.0.

\section{Results and discussion}

\section{Data validity and reliability}

The validity of the indicators of the latent variables was performed using confirmatory factor analysis (CFA) with the help of AMOS version 18.0 and the reliability of the indicators which were found valid was based on construct reliability performed with the help of Microsoft Excel.

Table 1. The results of validity and reliability tests

\begin{tabular}{|c|c|c|c|c|c|}
\hline Indicator variables & $\begin{array}{l}\text { Loading } \\
\text { factor }\end{array}$ & CR & $\mathbf{P}$ & Remarks & $\begin{array}{l}\text { Construct } \\
\text { reliability }\end{array}$ \\
\hline $\mathrm{X}_{11}$ & 0.562 & 5.107 & 0.000 & valid & \multirow{2}{*}{0.766} \\
\hline $\mathrm{X}_{12}$ & 0.980 & 4.816 & 0.000 & valid & \\
\hline $\mathrm{X}_{21}$ & 0.971 & 3.844 & 0.000 & valid & \multirow{2}{*}{0.827} \\
\hline $\mathrm{X}_{22}$ & 0.788 & 3.685 & 0.000 & valid & \\
\hline $\mathrm{X}_{31}$ & 0.799 & 3.761 & 0.000 & valid & \multirow{2}{*}{0.889} \\
\hline $\mathrm{X}_{32}$ & 0.791 & 3.920 & 0.000 & valid & \\
\hline $\mathrm{Y}_{11}$ & 0.934 & 4.626 & 0.000 & valid & \multirow{3}{*}{0.858} \\
\hline $\mathrm{Y}_{12}$ & 0.587 & 4.524 & 0.000 & valid & \\
\hline $\mathrm{Y}_{13}$ & 0.901 & 4.580 & 0.000 & valid & \\
\hline $\mathrm{Y}_{21}$ & 0.871 & 3.421 & 0.000 & valid & \multirow{3}{*}{0.954} \\
\hline $\mathrm{Y}_{22}$ & 0.960 & 3.625 & 0.000 & valid & \\
\hline$Y_{23}$ & 0.973 & 3.511 & 0.000 & valid & \\
\hline
\end{tabular}

Source: Author's own research results. 
The results presented in Table 1 show that all the indicator variables used to set up a latent variable in this research were valid and reliable. This is indicated by the value of the loading factor on all the indicators being above 0.5 and the value of the whole construct reliability latent variables being above 0.7 .

\section{Descriptive analysis}

Table 2 presents the descriptive statistics regarding the respondents' age.

Table 2. The characteristics of the sample by age

\begin{tabular}{|c|c|c|}
\hline Age category & Amount & Percentage (\%) \\
\hline 0 to 19 years & 5 & 4.17 \\
\hline 20 to 30 years & 23 & 19.17 \\
\hline 31 till 40 years & 42 & 35.00 \\
\hline 41 to 50 years & 40 & 33.33 \\
\hline Over 50 years & 10 & 8.33 \\
\hline Total & 120 & 100 \\
\hline
\end{tabular}

Sources: Authors' own primary data research.

The majority of the respondents have ages between 31 to 40 years (35.00\%), followed by those with and ages between 20 to 30 years (33.33\%) and ages between 20 to 30 years (19.17\%). Thus, the majority of BNI, BRI, Bank Mandiri customers have ages between 20 and 50 years. Moreover, as shown in Table 3, most of the respondents are PNS (33.33\%), followed by college students (25\%) and housewives (23.34\%).

Table 3. The characteristics of the sample by job

\begin{tabular}{|c|c|c|}
\hline Job category & Amount & Percentage (\%) \\
\hline Traders / Farmers & 7 & 5.83 \\
\hline PNS & 40 & 33.33 \\
\hline Housewife & 28 & 23.34 \\
\hline College student & 30 & 25.00 \\
\hline Others & 15 & 12.50 \\
\hline Total & 120 & 100 \\
\hline
\end{tabular}

Sources: Authors' own primary data research.

Table 4 presents a description of the respondents' answers for the indicators of economic content.

Table 4. The frequency distribution of economic content assessment $\left(X_{1}\right)$ responses

\begin{tabular}{|c|c|c|c|c|c|c|c|c|c|c|c|c|}
\hline \multirow{3}{*}{ Indicator } & \multicolumn{10}{|c|}{ Respondent's answer value } & \multirow{3}{*}{ Total } & \multirow{3}{*}{ Modus } \\
\hline & \multicolumn{2}{|c|}{1} & \multicolumn{2}{|c|}{2} & \multicolumn{2}{|c|}{3} & \multicolumn{2}{|c|}{4} & \multicolumn{2}{|c|}{5} & & \\
\hline & $\mathbf{F}$ & $\%$ & $\mathbf{F}$ & $\%$ & $\mathbf{F}$ & $\%$ & $\mathbf{F}$ & $\%$ & $\mathbf{F}$ & $\%$ & & \\
\hline $\mathrm{X}_{1.1}$ & - & - & 4 & 3.3 & 49 & 40.8 & 65 & 54.2 & 2 & 1.7 & 120 & 4 \\
\hline $\mathrm{X}_{1.2}$ & - & - & 7 & 5.8 & 49 & 40.8 & 61 & 50.8 & 3 & 2.5 & 120 & 4 \\
\hline $\mathrm{X} 1$ & & & & & & & & & & & & 4 \\
\hline
\end{tabular}

Sources: Authors' own primary data research. 
The description of the results in Table 4 regarding the respondents' assessment of the economic content $\left(\mathrm{X}_{1}\right)$ indicators is as follows:

1. Economic value indicator $\left(\mathrm{X}_{1.1}\right)$ : the majority $(54.2 \%)$ of the respondents agree (score 4 ) that this is satisfactory and $40.8 \%$ of respondents answered in a neutral manner (score 3). This indicates that the majority of respondents assess that there is a consistency between costs and benefits for the customer after using the services of BNI, BRI, Bank Mandiri in East Java.

2. Switching cost indicator $\left(X_{1.2}\right)$ : the majority of the respondents $(50.8 \%)$ agreed (score 4) that the costs to switch to another bank are higher than the lack of benefits obtained by remaining a customer of BNI, BRI and Bank Mandiri and $40.8 \%$ of the respondents answered neutrally (score 3). Thus, for most of the customers, the switching costs are an important incentive for maintaining the relationship with their current bank.

Table 5 presents a description respondents' answers for the indicators of resource content.

Table 5. The frequency distribution of answers for resource content $\left(X_{2}\right)$

\begin{tabular}{|c|c|c|c|c|c|c|c|c|c|c|c|c|}
\hline \multirow{3}{*}{ Indicator } & \multicolumn{7}{|c|}{ Respondent's answer value } & \multirow{3}{*}{ Total } & \multirow{2}{*}{ Modus } \\
\cline { 2 - 12 } & $\mathbf{1}$ & \multicolumn{2}{|c|}{$\mathbf{2}$} & \multicolumn{2}{|c|}{$\mathbf{3}$} & \multicolumn{2}{|c|}{$\mathbf{4}$} & \multicolumn{2}{|c|}{$\mathbf{5}$} & \\
\cline { 2 - 12 } & $\mathbf{F}$ & $\mathbf{\%}$ & $\mathbf{F}$ & $\mathbf{\%}$ & $\mathbf{F}$ & $\mathbf{\%}$ & $\mathbf{F}$ & $\mathbf{\%}$ & $\mathbf{F}$ & $\mathbf{\%}$ & & \\
\hline $\mathrm{X}_{2.1}$ & - & - & 22 & 18.3 & 63 & 52.5 & 34 & 28.3 & 1 & 0.8 & 120 & 3 \\
\hline $\mathrm{X}_{2.2}$ & - & - & 19 & 15.8 & 60 & 50.0 & 40 & 33.3 & 1 & 0.8 & 120 & 3 \\
\hline $\mathrm{X}_{2}$ & & & & & & & & & & & & 3 \\
\hline
\end{tabular}

Sources: Authors' own primary data research.

Based on Table 5 we can describe the respondents' answers for each indicator of resource content $\left(\mathrm{X}_{2}\right)$ as follows:

1. Bank's reputation indicators $\left(X_{2.1}\right)$ : the majority of the respondents $(52.5 \%)$ answered neutrally and $28.3 \%$ answered in a positive manner, so it can be concluded that the majority of respondents consider that the reputation of BNI, BRI and Bank Mandiri is acceptable.

2. Confidence benefit indicator $\left(\mathrm{X}_{2.1}\right)$ : the majority of the respondents $(50.0 \%)$ answered neutrally and $33.3 \%$ answered positively. This indicates that the majority of respondents considered BNI, BRI, Bank Mandiri can guarantee the safety of the investments of its customers.

Table 6 presents a description of respondent's answers for the social content indicators.

Table 6. The frequency distribution rate of the answers for social content $\left(X_{3}\right)$

\begin{tabular}{|c|c|c|c|c|c|c|c|c|c|c|c|c|}
\hline \multirow{3}{*}{ Indicator } & \multicolumn{10}{|c|}{ Respondent's answer value } & \multirow{3}{*}{ Total } & \multirow{3}{*}{ Modus } \\
\hline & \multicolumn{2}{|c|}{1} & \multicolumn{2}{|c|}{2} & \multicolumn{2}{|c|}{3} & \multicolumn{2}{|c|}{4} & \multicolumn{2}{|c|}{5} & & \\
\hline & $\bar{F}$ & $\%$ & $\mathbf{F}$ & $\%$ & $\mathbf{F}$ & $\%$ & $\mathbf{F}$ & $\%$ & $\mathbf{F}$ & $\%$ & & \\
\hline$\overline{X_{3.1}}$ & - & - & 5 & 4.2 & 29 & 24.2 & 74 & 61.7 & 12 & 10.0 & 120 & 4 \\
\hline $\mathrm{X}_{3.2}$ & - & - & 2 & 1.7 & 31 & 25.8 & 83 & 69.2 & 4 & 3.3 & 120 & 4 \\
\hline $\mathrm{X}_{3}$ & & & & & & & & & & & & 4 \\
\hline
\end{tabular}

Sources: Authors' own primary data research 
Based on Table 6, the description of respondents' answers for social content indicators $\left(\mathrm{X}_{3}\right)$ is as follows:

1. Communication indicator $\left(\mathrm{X}_{3.1}\right)$ : the majority of the respondents $(61.7 \%)$ answered positively and $24 \%$ answered neutrally. These data indicate that the majority of the respondents is satisfied with the communication with the employees of BNI, BRI and Bank Mandiri when making a transaction.

2. Familiarity indicator $\left(\mathrm{X}_{3.2}\right)$ : the majority of the respondents (69.2\%) answered positively and $25.8 \%$ answered neutrally, so it can be concluded that the majority of the respondents considered that BNI, BRI and Bank Mandiri employees recognize and treat customers personally during interactions.

Table 7 presents a description of respondent's answers for the indicators of confidence.

Table 7. The frequency distribution rate of the answers for trust $\left(Y_{1}\right)$

\begin{tabular}{|c|c|c|c|c|c|c|c|c|c|c|c|c|}
\hline \multirow{3}{*}{ Indicator } & \multicolumn{10}{|c|}{ Respondent's answer value } & \multirow{3}{*}{ Total } & \multirow{3}{*}{ Modus } \\
\hline & \multicolumn{2}{|c|}{1} & \multicolumn{2}{|c|}{2} & \multicolumn{2}{|c|}{3} & \multicolumn{2}{|c|}{4} & \multicolumn{2}{|c|}{5} & & \\
\hline & $\mathbf{F}$ & $\%$ & $\mathbf{F}$ & $\%$ & $\mathbf{F}$ & $\%$ & $\mathbf{F}$ & $\%$ & $\mathbf{F}$ & $\%$ & & \\
\hline $\mathrm{Y}_{1.1}$ & - & - & - & - & 25 & 20.8 & 92 & 76.7 & 3 & 2.5 & 120 & 4 \\
\hline $\mathrm{Y}_{1.2}$ & - & - & 2 & 1.7 & 31 & 25.8 & 83 & 69.2 & 4 & 3.3 & 120 & 4 \\
\hline $\mathrm{Y}_{1.3}$ & - & - & - & - & 42 & 35.0 & 72 & 60.0 & 6 & 5.0 & 120 & 4 \\
\hline $\mathrm{Y}_{1}$ & & & & & & & & & & & & 4 \\
\hline
\end{tabular}

Sources: Authors' own primary data research

The descriptions of the answers presented in Table 7 for trust indicators are as follows:

1. Bank employees can be trusted indicator $\left(\mathrm{Y}_{1.1}\right)$ : the majority of the respondents (76.7\%) answered positively, and $20.8 \%$ answered neutrally, which means that the majority of the respondents believe and trust the employees of BNI, BRI and Bank Mandiri.

2. Bank reliable indicator $\left(Y_{1.2}\right)$ : the majority of the respondents $(69.2 \%)$ answered positively, and 25.8 answered neutrally. This proves that the majority of the respondents considered BNI, BRI and Bank Mandiri a bank demonstrates reliability in providing services to its customers.

3. Employee integrity indicator $\left(Y_{1.3}\right)$ : the majority of the respondents $(60.0 \%)$ answered positively, and $35.0 \%$ answered neutrally, which indicates that the majority of the respondents believe that BNI, BRI and Bank Mandiri employees have a good morale and are sincere in their dealing with customers.

Table 8 presents a description of the respondents' answers for the indicators of relationship intention. Based on the contents of the table we can observe the following:

1. Forgive indicator $\left(\mathrm{Y}_{2.1}\right)$ : the majority of the respondents $(55.8 \%)$ answered neutrally, and $35.8 \%$ answered positively, which means that the majority of the customers are still willing to forgive if occasionally BNI, BRI and Bank Mandiri cannot provide the service as expected by them.

2. Feedback indicator $\left(\mathrm{Y}_{2.2}\right)$ : the majority of the respondents $(44.25 \% \%)$ answered positively, and $42.5 \%$ of the respondents neutrally, which means that the majority of 
respondents will provide feedback or information about products, services, and expectation to BNI, BRI and Bank Mandiri.

3. Fear of losing relationship indicator $\left(\mathrm{Y}_{2.3}\right)$ : most of the respondents $(45.0 \%)$ answered positively and $43.3 \%$ of the respondents answered neutrally. This condition provides information that some of the respondents fear losing the relationship with BNI, BRI and Bank Mandiri, so they prefer to stay as customers.

Table 8. The frequency distribution rate of answers for relationship intention $\left(Y_{2}\right)$

\begin{tabular}{|c|c|c|c|c|c|c|c|c|c|c|c|c|}
\hline \multirow{3}{*}{ Indicator } & \multicolumn{8}{|c|}{ Respondent's answer value } & \multirow{2}{*}{ Total } & \multirow{2}{*}{ Modus } \\
\cline { 2 - 13 } & $\mathbf{1}$ & \multicolumn{2}{|c|}{$\mathbf{2}$} & \multicolumn{3}{|c|}{$\mathbf{3}$} & \multicolumn{2}{|c|}{$\mathbf{4}$} & \multicolumn{2}{|c|}{$\mathbf{5}$} & & \\
\cline { 2 - 13 } & $\mathbf{F}$ & $\mathbf{\%}$ & $\mathbf{F}$ & $\mathbf{\%}$ & $\mathbf{F}$ & $\mathbf{\%}$ & $\mathbf{F}$ & $\mathbf{\%}$ & $\mathbf{F}$ & $\mathbf{\%}$ & & \\
\hline $\mathrm{Y}_{2.1}$ & - & - & 3 & 2.3 & 67 & 55.8 & 43 & 35.8 & 7 & 5.8 & 120 & 3 \\
\hline $\mathrm{Y}_{2.2}$ & - & - & - & - & 51 & 42.5 & 53 & 44.2 & 16 & 13.3 & 120 & 4 \\
\hline $\mathrm{Y}_{2.3}$ & - & - & - & - & 52 & 43.3 & 54 & 45.0 & 14 & 11.7 & 120 & 4 \\
\hline $\mathrm{Y}_{2}$ & & & & & & & & & & & & 4 \\
\hline
\end{tabular}

Sources: Authors' own primary data research

The SEM analysis results obtained with Amos Version 18 are presented in Figure 2.

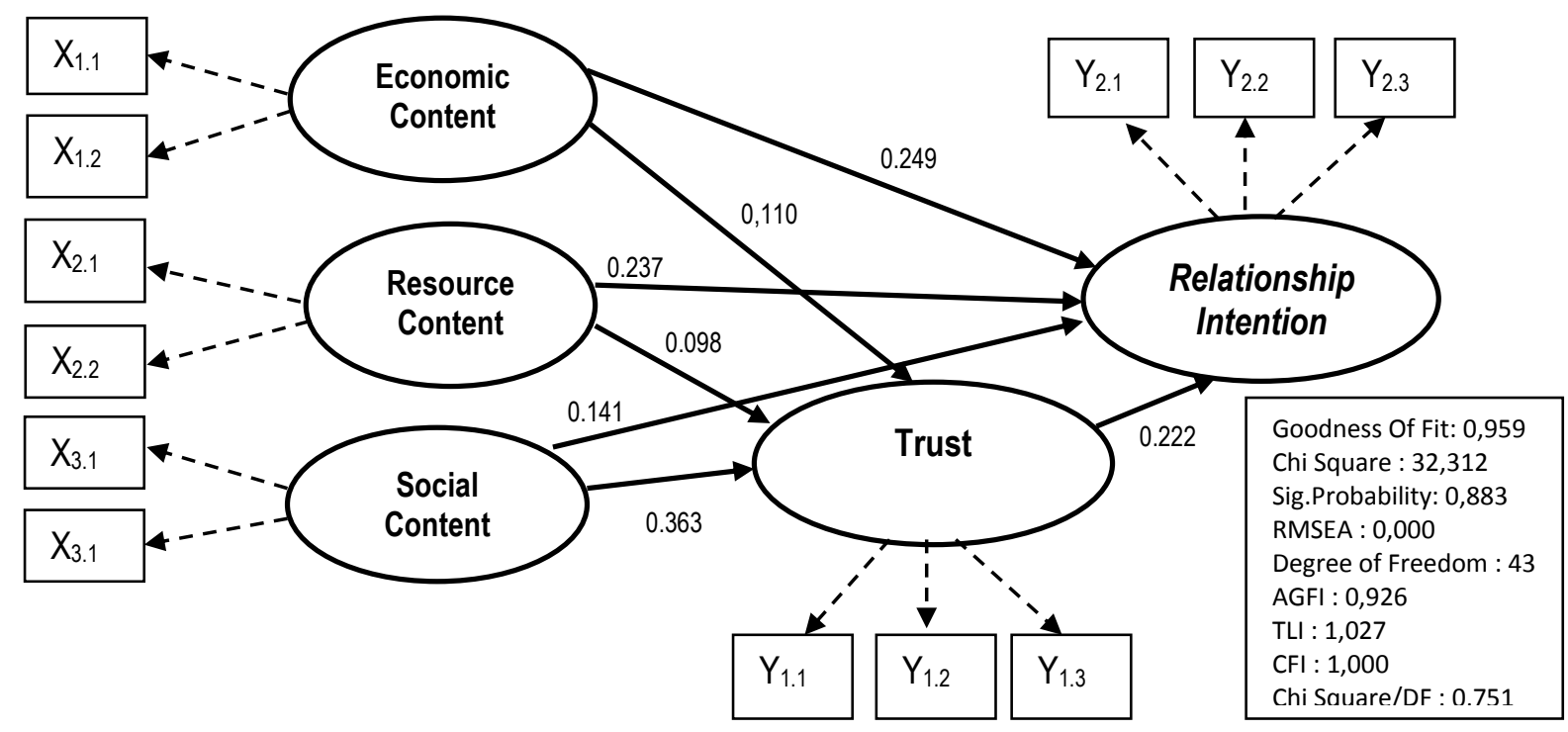

Figure 2. The model of economic, resource and social content as predictors of relationship intention with customer trust as mediator

Source: Authors' own research results.

The result shows that the research data has met the SEM precondition of assumptions model with multivariate CR value of 1.266 because this value lies between 1.96 and 1.96 (the critical value at the 0.05 significance level is 1.96). It can be said that the multivariate data is normal. The value of the determinant of the sample covariance matrix is 1.096 and this value is different than zero. The result shows that there are no multicollinearity and singularity problems for the analyzed data. There are no outliers in 
the data because the value of all Mahalanobis distances were under $21.026\left(\chi^{2} \mathrm{df}\right.$ : 12 (the sum of indicator)).

Table 9 shows the result of the SEM model's feasibility testing. These prove that the model is fulfilling all the best fit criteria model, so the model can be accepted. It means that there is a match between the model and the data.

Table 9. The test of congruity between SEM model and data

\begin{tabular}{|c|c|c|c|}
\hline Criteria & Cut - off value & $\begin{array}{c}\text { The } \\
\text { calculation } \\
\text { results }\end{array}$ & Remark \\
\hline Chi - Square & $\begin{array}{c}\text { Expected to be small (below the } \\
\left.\left.\text { value } \chi^{2} \text { table }_{(\chi 2} \text { df }: 43\right)=59,3051\right)\end{array}$ & 32.312 & Match \\
\hline Sig. probability & $\geq 0.05$ & 0.883 & Match \\
\hline RMSEA & $\leq 0.08$ & 0.000 & Match \\
\hline GFI & $\geq 0.90$ & 0.959 & Match \\
\hline AGFI & $\geq 0.90$ & 0.926 & Match \\
\hline CMIN / DF & $\leq 2.00$ & 0.751 & Match \\
\hline TLI & $\geq 0.95$ & 1.027 & Match \\
\hline CFI & $\geq 0.95$ & 1.000 & Match \\
\hline
\end{tabular}

Source: Authors' own research results.

Table 10 shows the results of the hypothesis testing, results which are discussed in detail below.

Table 10. The results of hypothesis testing

\begin{tabular}{|c|c|c|c|c|c|c|}
\hline & & & Estimate & CR & $\mathbf{P}$ & Remark \\
\hline Trust & $<--$ & Economic content & 0.110 & 2.499 & 0.031 & Significant \\
\hline Trust & $<---$ & Resource content & 0.098 & 1.966 & 0.046 & Significant \\
\hline Trust & $<---$ & Social content & 0.363 & 1.960 & 0.050 & Significant \\
\hline $\begin{array}{l}\text { Relationship } \\
\text { intention }\end{array}$ & $<---$ & Economic content & 0.249 & 2.196 & 0.028 & Significant \\
\hline $\begin{array}{l}\text { Relationship } \\
\text { intention }\end{array}$ & $<---$ & Resource content & 0.237 & 2.647 & 0.008 & Significant \\
\hline $\begin{array}{l}\text { Relationship } \\
\text { intention }\end{array}$ & $<---$ & Social content & 0.141 & 1.982 & 0.030 & Significant \\
\hline $\begin{array}{l}\text { Relationship } \\
\text { intention }\end{array}$ & $<---$ & Trust & 0.222 & 2.212 & 0.027 & Significant \\
\hline
\end{tabular}

Source: Authors' own research results.

\section{Hypothesis $1\left(\mathrm{H}_{1}\right)$}

Table 10 shows that economic content is a positive and significant predictor for customer trust. The evidence comes from the fact that the path is marked positive with a coefficient of 0.110 and CR values of 2.499 and a significance probability (p) of 0,031 . This value is smaller than the significance level $(\alpha)$ which is set at 0.05 . Thus, the first research hypothesis $\left(\mathrm{H}_{1}\right)$ is proven. This condition implies that when the banks are able to increase the amount of economic content, this will also increase the level of customer 
trust. Therefore, in order to increase the confidence of its customers, the bank must continue to increase the economic value of the content provided to its customers.

Customers believe that the bank can provide economic benefits to them, because they consider that the bank has the capability to meet their expectations. This is in accordance with the opinion of Donney and Cannon (1997) which state that customers' trust can be developed through various processes, but mainly through capability assessment, which is a test of the ability of others to meet their obligations. This will motivate customers to trust the service provider which offers economic content because provision of services is defined as the capability of the service provider.

An economic value is associated with the customer's perception of the cost-benefit ratio. The basic assumption of the cost-benefit ratio is that a customer is willing to establish a relationship with the bank because they consider the cost and the benefit arising from the relationship between customers and banks. Customers will establish a relationship with a bank that can provide the highest economic value among the existing banks. Value is the difference from the benefits received compared to the costs incurred in establishing a relationship with the bank. Banks that are able to provide a higher economic value than the cost for customers to obtain this value will be selected to form a relationship. Furthermore, switching costs describe the difficulty to find a new supplier (Anton et al., 2007). Customers do not want to move to other banks due to several barriers such as transaction costs and the cost of learning, discounts for loyalty, habits, emotional costs, and cognitive efforts, as well as the other financial, social and psychological risks. A customer who is aware of the existence of cost and the difficulty to get out of the relationship will tend to retain the relationship with the current service providers. In general, one party will be more dependent on other parties because the switching cost for other partners is larger. This means that the customer becomes trapped by the existing service providers because the switching costs are high. This situation is also happening to BNI, BRI and Bank Mandiri customer in East Java, the majority of whom are civil servants, housewife, and students. All of them because of their interest have to rely on government banks such as BNI, BRI and Bank Mandiri. This situation is in line with the opinion of Dwyer et al. (1987) which states that customers will remain in a relationship with a company, if the customers are faced concrete switching cost or if the customers cannot easily get the desired products or services from other partners. This finding is consistent with the results of Lin et al. (2003) who found a significant effect of the economic ties on customer trust.

\section{Hypothesis $2\left(\mathrm{H}_{2}\right)$}

Table 10 shows that resources content is a positive and significant predictor for customer trust. The evidence comes from the fact that the path is marked positive with a coefficient of 0.098 with CR values of 2,536 and a significance probability (p) of 0.011 . The p value is less than the significance level $(\alpha)$ which is set at 0.05 . These results provide support for the second hypothesis in this study. It means that better resource content owned by BNI, BRI and Mandiri Bank will lead to higher customer confidence in the BNI, BRI and Bank Mandiri.

The ownership of resources by a bank is important and will lead to customer trust and intention to remain a customer of the bank. Essential resources include the bank's reputation. The company's reputation is the customer's perception of the quality which is associated with the name of the company (Keller in Lacey, 2003). This implies that the 
company's reputation has a positive effect on customer response to the company's products or services. Reputation stays in the minds of the customers; customers assume that a reputable bank is a bank that is able to provide excellent service and good financial performance. These conditions can lead to customer confidence. Other unique resources that can increase customer confidence are confidence benefits and psychological benefits. A psychological benefit gained by customers is the convenience or the feeling of safety in developing relationships with service providers. Those customers who are sure that they will be treated well by the bank, will have a high confidence in remaining a customer of the bank. This finding is consistent with the research of Lacey (2003) who found a significant effect of resource content on customer confidence. Customers trust banks with good resource content and, in this case, they are willing to develop a relationship with the bank.

\section{Hypothesis $3\left(\mathrm{H}_{3}\right)$}

Table 10 shows that social content is a positive and significant predictor of customer trust. The evidence comes from the fact that the path is marked positive with a coefficient of 0,363 with CR value of 1,960 and a significance probability (p) of 0,050 . The p-value is smaller than the significance level $(\alpha)$ which is set at 0.05 . These results provide support for the third hypothesis. This means that the better the social content is formed between the bank and its customers, the higher the confidence of customer in the bank.

Interaction activities are assessed based on the customer's perception of the quality of the communication activities that are carried out intensively between the bank and its customers. Communication consists of all the bank marketing activities for its customers, which provide benefits and value to its customers. Communication is very important for the creation of an understanding of the desires and capabilities of each exchange partner, so that the relationship will be established. Good communication is a prerequisite in building confidence between exchange partners. Communications made between the bank and its customers will generate understanding for the customers of the benefits and the use of the services. Any kind of valuable information will affect the success of relationship marketing. A further communication can be made to provide information to the parties involved in the exchange when developing a relationship.

Familiarity is achieved through personalized activities, meaning the provision of personal attention to customers. Bank employees can provide some time to discuss the financial problems faced by customers. The interactions that occur between the customer and the employee can provide opportunities for employees to build customer relationships and increase familiarity. The interaction can develop into friendship between customers and bank employees. When there is personal relation, then the confidence to build and maintain a long-term relationship will increase.

Social interactions enable the customer to assess the knowledge and practices of the bank employees in serving and providing information about the products or services of the bank. Later on, the employee will give advice to customers on the results of these interactions. The results of these interactions can lead to customer confidence. Personal relationships between customers and bank employees will become the basis for building confidence and trust. Thus, the relationship is getting stronger. Conformity assessment lies in the words and actions of both sides. So, in fostering this relationship, both sides will provide norms and mutual responsibilities. Through interaction and observation of the 
behavior of partners, the two sides will assess their suitability. The frequent interactions between customers and bank employees will be able to resolve any dispute, correct perceptions and expectations as well as encourage their mutual trust.

These findings are supported by the results of Lacey's research (2003) who found that social content has a positive effect on trust. Social content can encourage a correct understanding, making it easier for both parties to trust each other. Furthermore, Lin et al. (2003) found that social ties have a significant effect on customer confidence. These results indicate that the development of confidence depends on the ability of the parties to predict the behavior of the other party. Their repeated interaction between customer and service provider helps customers assess the credibility and the quality of the service providers. Therefore, strong social ties can contribute to a better level of confidence.

\section{Hypothesis $4\left(\mathrm{H}_{4}\right)$}

Table 10 shows that economic content is a positive and significant predictor of customer's relationship intention. The evidence comes from the fact that the path is marked positive with a coefficient of 0.249 with CR values of 2.196 and a significance probability (p) of 0.028. These results provide support for the fourth hypothesis of the study. This means that the higher the economic content is received by the customer, the greater customer trust in the bank. Customers are willing to continue a relationship with a bank that can provide high economic benefits to them. The relationship intention of customers will emerge through a process of interaction between them and the bank. Partners will assess the capability of exchange partners which is derived from an assessment of their exchange partner's ability to meet its obligations. This situation can motivate customers to trust the service providers that offer high economic content as the party that has such capability.

\section{Hypothesis $5\left(\mathrm{H}_{5}\right)$}

Table 10 shows that resource content is a positive and significant predictor for customer relationship intention. The evidence comes from the fact that the path is marked positive with a coefficient of 0.237 with CR values of 2,647 and a significance probability (p) of 0.008. These results mean that the fifth hypothesis has to be accepted. These results indicate that customers are willing to establish continuous relationships with BNI, BRI, and Mandiri Bank, as customers believe that the three banks have reliable resources to meet the needs and wants of their customers. Resources possessed by the bank are very important for customers as they signal the fact that the bank is capable of meeting their expectations. As such, the bank's capability will increase the willingness of the customers to enter into a relationship with the bank.

\section{Hypothesis $6\left(\mathrm{H}_{6}\right)$}

Table 10 shows that social content is a positive and significant predictor of customer relationship intention. The evidence comes from the fact that the path is marked positive with a coefficient of 0.141 with CR values of 1982 and a significance probability (p) of 0,030 . These results provide support for the sixth hypothesis. This shows that thesocial content of BNI, BRI, and Bank Mandiri helps customers build a positive appraisal of the knowledge of the banks' employees and of the way in which employees act while serving 
and providing information about products and services offered by the bank to its customers, so customers are willing to keep in touch constantly with the bank.

The social interaction that occurs enables customers to assess the knowledge and practice of bank employees in serving and providing information to the customers regarding the products and services. The way in which this interaction unfolds can lead to customers' wanting to develop a relationship. Personal relationships between customers and bank employees are the foundation on which customers build their confidence. Customers will evaluate the suitability of expected bank's performance and the quality of the service. Consumer confidence will increase the tendency for a stronger long-term customer's relationship with the bank. This happens because in the process of the relationship both parties will respect each other by obeying the agreed norms and mutual responsibilities. Thus, both parties understand each other and are willing to provide the best value to their partners in the exchange process. Such conditions will ensure the continuity of relationships in the long run.

\section{Hypothesis $7\left(\mathrm{H}_{7}\right)$}

Table 10 shows that trust is a positive and significant predictor of customer relationship intention. The evidence comes from the fact that the path is marked positive with a coefficient of 0.222 with CR values of 2.212 and a significance probability (p) of 0,027. These results provide support for the seventh research hypothesis.

The finding indicates that BNI, BRI and Bank Mandiri customers in East Java have had a confidence in the bank and that this confidence has made the customers decide to establish continued relationships with BNI, BRI and Bank Mandiri. The finding also suggests that the level of trust is a predictor of the customer's decision to remain in the relationship. Customer confidence in the bank rises because customers have gained maximum returns on their investments. Convinced customers are willing to conduct personal business and to make some sacrifices to maintain the existing relationship. Trust in a relationship creates a desire to develop a stable relationship, the willingness to sacrifice short-term interests in order to achieve long-term profitability for defending relationship, and trust in the stability of the relationship itself.

Trust plays an important role in building and developing relationship marketing. Customer trust occurs when one party has confidence that the partner has reliability and integrity in exchange. Trust is a powerful contributor to relationship intention. Trust is modeled as the advance of relationship intention because consumers may be less interested in developing an intention for a relationship with the company, if trust has not been previously awakened. Trust reduces uncertainty and vulnerability, especially in the case of those services that are difficult to evaluate because it they intangible, complex and technical. Banking products are intangible products that require greater quality experience and can only be evaluated after purchasing. Certain attributes cannot be evaluated by the customer until the purchase and are usually technically complex. Some attributes can be referred to as credence qualities because customers believe in the quality of the products based on the words of other customers. Customers often have difficulty in assessing the quality of the products or services of the bank. Thus, the value of banking products must be placed in trust. Customers will state that they trust the bank, because they depend on the services provided by the bank. 
Customers' confidence in the bank is an important trigger for the relationship with a bank and is the most intangible assessment. The trigger creates a reciprocity emotion during the contact. Customers feel an emotional bond with the bank. Customers often say that a the developing of feelings of trust and familiarity when conducting a transaction with a bank is the reason that makes them use the services of the bank repeatedly. A close relationship between the customers and bank employees makes customers comfortable in doing transactions with the bank. The emotional bond is what makes customers have a strong desire to continue a relationship with a bank. Customers which have acknowledged their feelings about close relation with the bank will have a good comfortable level in dealing with banks. Customers want to remain in contact with the bank because customers feel that it is important to maintain the relationship. The findings of this study support those of Venetis and Ghauri (2004) who showed that trust is an intermediate variable that plays an important role in forming long-term relationships. Customers who believe in the relationship will have a greater tendency to remain in contact with the company, because of the need to stay consistent with their beliefs (Moorman et al., 1993).

The existence of positive and significant impact of trust on the relationship intention shows that customers are willing to forgive the bank if the bank occasionally cannot meet their expectations. Customers are willing to provide a feedback and fear of losing the relationship with the bank. Relationships that have been well established between customers and banks will lead to a strong desire of customers to establish a sincere relationship with the bank. These kinds of customers are more likely to forgive and give a second chance for banks to correct their mistake, for certain reasons. In addition, these customers are willing to give feedback to the banks by providing an opportunity for the bank to get to know them and their needs by giving information to the bank. Customers willing to provide information to banks about products and services have received either good or bad information. Feedback given to the bank by their customers will help the bank determine the level of customer satisfaction. Banks will be able to know what customers are thinking. Therefore, banks should encourage their customers to give feedback and routinely collect and then analyze the feedback received. Customers who already feel at ease and comfortable in interacting and transacting with the bank's employees will be happy to continue the relationship and will fear losing the relationship with the bank.

\section{Trust as mediator in the relation between economic content, resource content, social content and relationship intention}

This analysis is done by comparing the magnitude of the direct effect of economic content, resource content, social content on relationship intention with the magnitude of the indirect effect of economic content, resource content, social content on relationship intention through the mediation of customer trust. If the direct effect value is greater than that of the indirect effect, the mediating role of trust is smaller than the direct influence of economic content, resource content, and social content on relationship intention. And if the value of the direct effect is smaller than the value of the indirect effect, then the mediation role of trust is higher than the direct influence of economic content, resource content, social content on relationship intention (Dimyati, 2015). 
Table 11. The effects among the research variables

\begin{tabular}{|c|c|c|c|}
\hline \multirow{2}{*}{\multicolumn{2}{|c|}{ Standardized direct effects }} & \multicolumn{2}{|c|}{ Endogenous variable } \\
\hline & & Trust & Relationship intention \\
\hline \multirow{4}{*}{ Exogenous variable } & Economic content & 0.110 & 0.249 \\
\hline & Resource content & 0.098 & 0.237 \\
\hline & Social content & 0.363 & 0.141 \\
\hline & Trust & 0.000 & 0.222 \\
\hline \multirow{2}{*}{\multicolumn{2}{|c|}{ Standardized indirect effects }} & \multicolumn{2}{|c|}{ Endogenous variable } \\
\hline & & Trust & Relationship intention \\
\hline \multirow{4}{*}{ Endogenous variable } & Economic content & 0.000 & 0.025 \\
\hline & Resource content & 0.000 & 0.022 \\
\hline & Social content & 0.000 & 0.081 \\
\hline & Trust & 0.000 & \\
\hline
\end{tabular}

The results of the analysis in Table 11 show that the direct effect of economic content, resource content, social content to the customer relationship intention is greater than the indirect effect of economic content, resource content, social content to the customer relationship intention with the mediation of customer trust. It means that the role of economic content, resource content, and social content is greater as the direct predictor of relationship intention than as the role of mediating on trust. Although the mediating role of trust is lower, it still has a significant mediating role, so trust also has an important role in mediating the influence of economic content, resource content, social content on the customer relationship intention of BNI, BRI, Bank Mandiri customers in East Java. These findings support the results of research of Venetis and Ghauri (2004) and Dimyati (2010) who found that trust is an intermediate variable which plays an important role in forming long-term relationships.

\section{Conclusions}

Economic, resource and social content were found to be positive and significant predictors of customer trust in the case of the BNI, BRI and Bank Mandiri customers in East Java. This means that a higher the level of economic, resource and social content given by BNI, BRI and Bank Mandiri to its customers leads to higher levels of customer trust in the BNI, BRI and Bank Mandiri. Moreover, economic, resources and social content were also found to be positive and significant predictors of the customers' relationship intention in the case of the customers of BNI, BRI and Bank Mandiri in East Java. This means that the higher the economic, resource and social content is received by the customer, the higher the customers' trust in BNI, BRI and Bank Mandiri will be.

Trust was also found to be a positive and significant predictor of customer relationship intention in the case of the customers of BNI, BRI and Bank Mandiri. These results indicate that the customers of BNI, BRI and Bank Mandiri have had trust in the bank and that this trust influenced the customers' decision to continue their relationships with BNI, BRI and Bank Mandiri. The role of economic content, resource content, and social content is higher as predictors of relationship intention compared to the mediating role of 
trust. Trust plays a critical role in mediating the influence of economic content, resource content, and social content on the customers' relationship intention in the case of BNI, BRI Bank Mandiri customers in East Java.

Based on these findings, we have developed a series of suggestions for the banks included in our study. First of all, BNI, BRI and Bank Mandiri in East Java should always try to improve the trust and customer relationship intention by increasing the economic content, resource content, and social content. Increasing the economic content can be done by increasing the cost-benefit ratio of customers through an increase of the value of benefits received by customers that should be higher than the costs spent by customers to acquire those benefits. Improving resource content can be done by increasing the bank's reputation and the security provided to its customers. Improving the ability of the employees to interact with customers can be achieved by improving the ability to use language that is easily understood by customers, the ability to listen and respond to customer complaints and to provide solutions that can be well received by customers. Secondly, BNI, BRI and Bank Mandiri in East Java must try to improve customer trust by improving the knowledge and skills of employees, which means reducing the number of mistakes, making sure that employees keep their promises and that they are transparent when providing information.

Further research can examine the use of the model developed in this study in other service sectors as consumer perceptions are very important in a buyer-seller relationship. The model also can be examined in other areas of relation, such as the relationship between the employer and employee or the relation between the company and its distributors.

\section{References}

Anton, C., Camarero, C. and Carero, M. (2007), “Analysing firm's failure as determinant of comsumer switching intention", European Journal of Marketing, Vol. 41, No.1/2, pp. $135-158$.

Barnes, J.G. (2003), Secrets of customer relationship management, Yogyakarta: Penerbit Andi.

Barney, J. (2001), "Firm resource and sustained competitive advantage", Journal of Marketing, Vol. 17, No. 1, pp. 178-186.

Beckett, A., Hewer, P. and Howcroft, B. (2000), "An exposition of customer behavior in the financial service industry", International Journal of Bank Marketing, Vol. 18, No. 1, pp. 15-26.

Bendapuli, N. and Leone, R.P. (2002), "Managing business to customer relationships: Following key contact employee turnover in vendor firm", Journal of Marketing, Vol. 66, No. 2, pp. 83-101.

Boonajsevee, B. (2005), "Relationship marketing: Loyalty intentions in new era of Thai bank marketing”, Dissertation, The Wayne Huizenga Graduate School of Business and Entrepreneurship, Nova Southeastern University.

Burnham T.A., Frels, J.K. and Mahajan, V. (2003), "Consumer switching costs: A typology, antecedents, and consequences", Journal of The Academy of Marketing Science, Vol. 31 , No. 2, pp. 109-121.

Dimyati, M. (2010), "Pengaruh struktural economic, resource, dan social content terhadap kepercayaan dan kepuasan serta komitmen dan relationship intention nasabah", 
JAM (Jurnal Aplikasi Manajemen) Fakultas Ekonomi Jurusan Manajemen Universitas Brawijaya Malang. Vol. 8, No. 2, pp. 577-587.

Dimyati, M. (2015), "The role of customer satisfaction in mediating marketing communication effect on customer loyalty", Researchers World: Journal of Arts Science and Commerce, Vol. 6, No. 1, pp. 75-87.

Donney, P.M. and Cannon, J.P. (1997), "An examination of the nature of trust in buyer-seller relationships", Journal of Marketing, Vol. 61, No. 2, pp. 35-51.

Dwyer, F.R., Schurr, P.H. and Oh, S. (1987), "Developing buyers-seller relationship", Journal of Marketing, Vol. 51, pp. 11-27.

Ferdinand, A. (2006), Metode penelitian manajemen. Edisi 2. Semarang: Universitas Diponegoro.

Ghozali, I. (2004), Model persamaan struktural. Konsep dan aplikasi program Amos Ver. 5.0. Semarang: Badan Penerbit UNDIP.

Gronroos, C. (1996), "Relationship marketing: strategic and tactical implementations", Management Decision, Vol. 34, No. 3, pp. 5-14.

Gwinner, K.P., Gremier, D.D. and Bitner, M.J. (1998), "Relational benefits in service industries: The consumer's perspective", Journal of The Academy of Marketing Service, Vol. 26, pp. 101-114.

Indriantoro, N., Supomo, B. (2002), Metodologi penelitian bisnis. Edisi Pertama, Yogayakarta: BPFE UGM.

Kumar, N., Bohling, T.R. and Ladda, R.N. (2003), "Antecedents and consequences of relationship intention: Implications for transaction and relationship marketing", Industrial Marketing Management, Vol. 23, pp. 667-676.

Lacey, R.W. (2003), "Customer loyalty programs: Strategic value to relationship marketing", Dissertation, Alabama: The Graduate School of University of Alabama.

Lavelock, C. (2004), Service marketing and management, New Jersey: Prentice Hall.

Lin, N.P., Weng, J.C.M. and Hsieh, Y.C. (2003), "Relational bonds and customer's trust and commitment - A study on the moderating effect of website usage in financial industry", The Service Industrial Journal, Vol. 23, No. 3, pp. 103-124.

Moorman, C., Zaltman G. and Deshpande, R. (1993), "Relationship between providers and users of market research: The dynamics of trust within and between organizations", Journal of Marketing Research, Vol. 29, pp. 314-328.

Morgan, R.M. (2000), "Relationship marketing and marketing strategy: The evolution of relationship marketing within the organization", In: Jagdish, N.S. and Parvatiyar, A. (Eds.), Handbook of relationship marketing, London: Sage Publications.

Morgan, R.M. and Hunt, S.D. (1994), "The trust theory of relationship marketing", Journal of Marketing, Vol. 58 No. 3, pp. 20-38.

Peppers, D. and Rogers, M. (2004), Managing customer relationships: A strategic framework, New Jersey: John Wiley \& Sons.

Peterson, R.A. (1995), "Relationship marketing and the consumer", Journal of the Academy of Marketing Science, Vol. 23, pp. 278-281.

Sekaran, U. (2003), Research methods for business: A skill building approach, USA: John Wiley and Sons.

Sheth, J.N. and Parvatiyar, A. (2000), Handbook of relationship marketing, London: Sage Publications. 
Venetis, K.A. and Ghauri, P.N. (2004), "Service quality and customer retention: Building long-term relationships", European Journal of Marketing, Vol. 38, No. 11/12, pp. 1577-1598.

Walter, A., Mueller, T.A. and Helfert, G. (2000), The impact of satisfaction, trust, and relationship value on commitment: Theoretical considerations and empirical results. Germany: University of Karlstruhe.

Zeithaml, V.A. and Bitner, M.J. (2003), Service marketing: Integrating customer focus across the firm, 3rd edition, New York: Irwin McGraw-Hill. 